\title{
EFFECTIVENESS IN IMPLEMENTING SUPREME COURT REGULATION OF THE REPUBLIC OF INDONESIA NUMBER 2 YEAR 2015 ON PROCEDURES SETTLEMENT OF SIMPLE LAWSUIT IN SETTLING THE CIVIL CASES Wiryatmo Lukito Totok \\ Judge of Kediri District Court, East Java, Indonesia \\ E-mail: judge_wlt17@yahoo.com
}

Anik Iftitah,

Faculty of Law, Balitar Islamic University, Blitar, East Java, Indonesia

E-mail:geest_willdaad@yahoo.com

\begin{abstract}
President Regulation of the Republic of Indonesia Number 2 Year 2015 on the National Medium Term Development Plan 2015-2019 mandates to carry out Reformation of the Civil Code system which is easy and fast, in an effort to improve the competitiveness of national economy. Related to this, the Supreme Court answered the vacancy of a simple lawsuit by issuing Regulation of the Supreme Court of the Republic of Indonesia (PERMA) Number 2 Year 2015 on procedures for settlement of simple suit in settling civil cases. The empirical juridical research in the Court of Kediri showed that the implementation of Regulation of the Supreme Court of the Republic of Indonesia Number 2 Year 2015 made the lawsuit procedure simpler and very effective and in accordance with the principle of simple, fast and light cost. Effectiveness Index of Regulation of the Supreme Court of the Republic of Indonesia Number 2 year 2015 at Kediri District Court Class I B was in the "good" category, influenced by substance rule of the law, legal culture, structure of the law, and community knowledge.
\end{abstract}

\section{Keywords: Effectiveness, Simple Lawsuit}

\section{Received: 07 January, 2017; Accepter: 15 March, 2017}

\section{INTRODUCTION}

The term simple lawsuit is something new in our legal system but in fact it is not new and has been developed both in countries that apply both the Common Law system and the Civil Law system named Small Claim Court.

Small Claim Court has grown and developed not only in developed countries such as America, Canada, England, Germany, Holland, but also in Latin America, Africa and Asia as Small Claim Court (SCC).

The concept of a small claims court is a legal entity intended to provide a fast and economical solution to resolve disputes that has light cost. Small claims court is an informal dispute settlement forum and relatively cheap court fee, with a small case value. This is in line 
JARES, Vol. 2 No. 1 March, 2017; p-ISSN: 2502-826X; e-ISSN: 2503-1163

Copyrights@ Balitar Islamic University, Blitar, Indonesia; Http://jares.unisbablitar.ejournal.web.id

Citation: Totok, Wiryatmo Lukito, et. al. 2017. Effectiveness in Implementing Supreme Court Regulation of The

Republic of Indonesia Number 2 Year 2015 on Procedures Settlement Of Simple Lawsuit in Settling the Civil Cases.

JARES, (2017), 2(1): 16-25

with the purpose of establishing a small claims court, which is to provide a dispute resolution formality with a small case value, uncomplicated court case to resolve a simple dispute that does not require a lot of money to guarantee the cost of formal litigation.

What about the implementation of small claims in Indonesia, according to the National Medium-Term Development Plan (RPJMN) 2015-2019 mandated to implement the Reformation of the Easy and Fast Civil Law System, is an effort to improve the competitiveness of the national economy. In order to realize the competitiveness, the development of national law should be directed to support the realization of sustainable economic growth; regulating issues related to the economy, especially the business and industry; as well as create investment certainty, especially enforcement and legal protection. Therefore, a systematic strategy is needed to revise legislation in the field of civil law in general as well as specifically related to contract law, intellectual property protection, the establishment of a small claim court, and increased utilization of mediation institutions.

Responding to this matter, according to its authority, the Supreme Court tries to answer the legal vacuum and matters that are not sufficiently regulated in the Law because it is based on the consideration that the existing civil law, whether HIR or RBG has not adopted the principle of lawsuit simple while the Civil Code bill until now also has not been discussed by the Parliament so that finally the Supreme Court felt the need to issue PERMA to fill legal needs.

Beginning with the formation of Working Group (Pokja) of Preparation of PERMA Settlement of Simple Claim Lawsuit based on decree KMA no. 267 / KMA / SK / X / 2013 until finally issued Regulation of the Supreme Court Number 2 Year 2015 on Procedures for Completion of Simple Claim (PERMA Number 2 Year 2015) which has been effectively implemented by all first instance court since enacted on 7 August 2015 in the State Gazette of the Republic of Indonesia Year 2015 Number 1172, using the name of a simple lawsuit and having a characteristic not much different from the Small Claim Court applicable in some countries but adapted to the conditions in Indonesia.

A simple lawsuit of PERMA Number 2 Year 2015 formulated as a matter of breach of appointment and / or unlawful action with the value of lawsuit at most Rp. 200,000,000.00 (two hundred million rupiahs), which is settled by simple procedure and verification.

\section{RESEARCH METHODS}

\section{a. Research Sites}

The location of the study is the place used in conducting research to obtain the desired data. The research was conducted at Court of Kediri District in Pamenang Street Number 60, Ngasem District, Kediri Regency.

\section{b. Design and Variable Research}

The specification of the research was analytical descriptive which aimed to obtain a thorough description of the effectiveness of PERMA implementation Number 2 Year 2015 procedures for 
settlement of simple suit as a civil dispute resolution mechanism that required a quick, simple and inexpensive solution. The obtained data were analyzed mixedly between the qualitative and quantitative, and then the results of the analysis were described in the form of research report.

\section{c. Population and Sample}

Sampling method used simple random sampling with population of this research was all society of service user and justice seeker at Court of Kediri Regency I B.

\section{d. Data Collection}

\section{Library Research / Normative Research Methods}

Library research was carried out by the author by collecting all data related to the issues raised, contained in literature, books, papers, mass media, electronic media, and legislation, and court decisions

\section{Field Research / Empirical Research Methods}

Empirical research is a study that examines legal theories can be applied within a given society and whether certain legal rules are adhered to by role-holders in social life. Legal studies using the empirical approach examine the following matters: the law is seen as an order of conduct or prohibition of doing something accompanied by sanctions so that the command or prohibition is obeyed. Field research was conducted by conducting interviews with Judges and Court Officials related to the formulation of this issue and conducting a survey of respondents in this case community of users of services and seekers of justice in Court of Kediri District, with quantitative methods and samples taken by the technique simple random sampling in the hope of providing an overview of the effectiveness of the implementation of Supreme Court Regulation No. 2 of 2015 on procedures for settlement of simple suit in settling civil cases in court.

\section{e. Data analysis}

Data analysis was carried out by the writer with obtained data from normative and empirical research and analyzed mixedly between quantitative and qualitative with empirical normative juridical approach.

The specification of the research was analytical descriptive which aims to obtain a thorough description of the effectiveness of PERMA implementation no. 2 Year 2015 on procedures for settlement of simple suit as a civil dispute resolution mechanism that requires a quick, simple and inexpensive solution. The obtained data were analyzed mixedly between the qualitative and quantitative, and then the results of the analysis were described in the form of research report.

\section{RESULTS AND DISCUSSIONS}

1. Implementation Of Regulation Of The Supreme Court (Perma) Number 2 Year 2015 On Procedures Settlement Of Simple Lawsuit In Settling The Civil Cases In The Court

In PERMA Number 2 Year 2015 Concerning the Procedures for Settlement of Simple Lawsuit has differences with the settlement of ordinary civil cases with the aim of accelerating the process of settlement of cases, namely: 
JARES, Vol. 2 No. 1 March, 2017; p-ISSN: 2502-826X; e-ISSN: 2503-1163

Copyrights@ Balitar Islamic University, Blitar, Indonesia; Http://jares.unisbablitar.ejournal.web.id

Citation: Totok, Wiryatmo Lukito, et. al. 2017. Effectiveness in Implementing Supreme Court Regulation of The

Republic of Indonesia Number 2 Year 2015 on Procedures Settlement Of Simple Lawsuit in Settling the Civil Cases.

JARES, (2017), 2(1): 16-25

First, a simple lawsuit case is recorded in a special register book, which is the Master Book of Special Register for Simple Lawsuit.

Second, simple civil lawsuits are examined and decided on two levels by the same District Court. At the first level, the case is examined and decided by a Single Judge that the settlement of a simple lawsuit case is limited by a period of no later than 25 working days. While at the level of legal remedy the objection is examined and decided by the Assembly Judge within 7 working days at the level of objection since the establishment of the Panel of Judges.

Third, the decision of the objection is final and binding and with a limited scope of examination, which includes: (a) a decision on a simple lawsuit file; (b) the objections proposal and objection memories; and (c) contra memory of objections. There are no additional checks on the objection and no further legal action after the objection.

Fourth, the process of simple lawsuit can not be filed provision, exception, reconvention, intervention, replication, duplicate, or inference

Fifth, in the examination of simple lawsuit cases the judge shall take an active role in the trial attended by the parties, especially if the parties are not educated by law and / or are not accompanied by legal counsel. This livelihood is aimed at: (1) providing a fair account of the simple lawsuit to the parties; (2) seeking peaceful settlement of the case including suggesting the parties to peace outside the trial; (3) guiding the parties in proof; and (4) explains the legal efforts that can be taken by the parties.

Sixth, in the absence of the Defendant, the Judge proceeded by examining and deciding the case without the presence of the Defendant in a contradictoir, which means that the ruling is valid in the ordinary lawsuit in case both parties are present so that there is no verzet legal action against the Verdict but the Defendant can still file legal action against the verdict by filing an objection.

The result of the research survey by using simple random sampling with the population of this research was all community of service users and justice seeker at Court of Kediri District I B got that PERMA Implementation Performance Index. 2 year 2015 about Simple Claim at Kediri District Court Class I B was 64,53\% in "GOOD" category (at interval 62.51 to 81.25). Details of the results of the above survey, consists of four scopes, the next analysis was to describe the analysis of the four scopes.

Score and Ranking on PERMA Implementation Survey Number 2 Year 2015 in the Court of Kediri District

\begin{tabular}{|l|l|l|c|c|}
\hline No & \multicolumn{1}{|c|}{ Scope } & $\begin{array}{l}\text { Averag } \\
\mathbf{e}\end{array}$ & $\begin{array}{c}\text { Categor } \\
\mathbf{y}\end{array}$ & $\begin{array}{c}\text { Ratin } \\
\mathbf{g}\end{array}$ \\
\hline 1. & $\begin{array}{l}\text { community knowledge about PERMA Number } \\
\text { 2 Year 2015 }\end{array}$ & 2,575 & Good & 3 \\
\hline 2. & $\begin{array}{l}\text { the settlement of civil disputes through the } \\
\text { mechanism of simple lawsuit (PERMA } \\
\text { Number 2 Year 2015) }\end{array}$ & 2,675 & Good & 1 \\
\hline
\end{tabular}


JARES, Vol. 2 No. 1 March, 2017; p-ISSN: 2502-826X; e-ISSN: 2503-1163

Copyrights@ Balitar Islamic University, Blitar, Indonesia; Http://jares.unisbablitar.ejournal.web.id

Citation: Totok, Wiryatmo Lukito, et. al. 2017. Effectiveness in Implementing Supreme Court Regulation of The

Republic of Indonesia Number 2 Year 2015 on Procedures Settlement Of Simple Lawsuit in Settling the Civil Cases.

JARES, (2017), 2(1): 16-25

\begin{tabular}{|l|l|c|c|c|}
\hline 3. & $\begin{array}{l}\text { settlement of cases in accordance with the } \\
\text { judicial principle "simple, fast and low cost" }\end{array}$ & 2,650 & Good & 2 \\
\hline 4. & content on PERMA Number 2 Year 2015 & 2,425 & $\begin{array}{l}\text { Less } \\
\text { good }\end{array}$ & 4 \\
\hline
\end{tabular}

In addition to getting the respondent's suggestions about the procedure of settlement of the case with a simple lawsuit, the authors also conducted interviews with judges of Court of Kediri District as follows:

Mrs. Lila Sari, S.H, M.H who said that simple lawsuit is a solution done by the Supreme Court overcome the problems that are often faced by people who actually the case can be resolved quickly because the proof is easy but because the procedure ranges from the first level to the level of appeal takes a very long time and the cases that make the buildup of cases in the Supreme Court. Then Imam Santoso, S.H, M.Hum explained that a Judge in settling the case must play an active role and can arrange the hearing considering the short time (twenty-five days) so that the parties really use the best time, and the settlement of the lawsuit case through the simple lawsuit mechanism is very in line with the principle of the trial which is simple, fast and low cost but still prioritizes the quality of the trial with the result is to achieve justice and useful so that it can resolve the dispute. Muhammad Fahmi, SH, MHum argued that the proceedings of court proceedings with simple court actions are truly effective and efficient because they override the trial process processes such as replicates, duplicates or conclusions that are time-consuming and the judges examining cases are made easier by the filing of evidence especially for the plaintiff at the time of the lawsuit has attached the evidence of his letter and the witnesses to be presented as well as the defendant who has presented the evidence at the time of the answer so that before examining the court hearing already know the legal facts. Meanwhile, according to Guntur Pambudi Wijaya, S.H, M.H simple lawsuit is one of the legal breakthrough made by the Supreme Court in civil proceedings in court compared with using the usual mechanism of settlement of lawsuit based on HIR and $\mathrm{RBg}$, although it has been arranged in addition to time which tend to be longer and consuming many costs because of the legal effort to the Supreme Court as well as some rules abolished in simple lawsuits make it easier (simpler) so that the judicial principles of "Simple, Fast and Lightweight Costs" can be achieved without reducing legal certainty, usefulness, and fairness. Based on the results of the research as described above, the authors argued that PERMA Number 2 Year 2015 on Procedures for Settlement of Simple Lawsuit, especially in the Court of Kediri District is effective as one solution to solve the case by applying the judicial principle "Simple, Fast and Light Cost" can be achieved and the result is accepted by the parties so as to avoid the accumulation of cases in the Supreme Court, although there are some weaknesses such as the number of simple lawsuit cases that enter was fewer than ordinary lawsuit case as a result of lack of socialization to be able to provide more insight to the community widely, especially to the public will be better to understand the law about the simple settlement of lawsuits in the district court through mass media and internet which will further be 
JARES, Vol. 2 No. 1 March, 2017; p-ISSN: 2502-826X; e-ISSN: 2503-1163

Copyrights@ Balitar Islamic University, Blitar, Indonesia; Http://jares.unisbablitar.ejournal.web.id

Citation: Totok, Wiryatmo Lukito, et. al. 2017. Effectiveness in Implementing Supreme Court Regulation of The

Republic of Indonesia Number 2 Year 2015 on Procedures Settlement Of Simple Lawsuit in Settling the Civil Cases.

JARES, (2017), 2(1): 16-25

discussed in the factors that affect the implementation of procedures settlement in Simple Lawsuit.

\section{Factors That Affect Implementations On The Procedures Of Simple Settlement Of Simple}

In the research, there are several factors that influence the implementation of the Procedure of Settlement of Simple Lawsuit, especially negative factor which is considered as something that influences the lack of success of PERMA.

a. Substance Rule of The Law Factors

1. In the PERMA of Simple Lawsuit recognizes one form of legal remedy against the judge's decision, namely the right to file an objection. The simplification of the types of legal remedies in simple lawsuits ranging from the stages, the period of filing to the objection check process intended to make the civil proceedings simple. A legal effort shall be filed no later than 7 days after the decision is made or after the notification of the decision in the event that the Defendant is absent may raise legal issues if it is related to the provisions concerning the filing of a legal remedy for verdict verstek (verzet). Indeed, in the case of the defendant is not present in the simple suit of the lawsuit, the trial is continued and terminated without the presence of the defendant, but the verdict is not a verdict of the vertecraft but the contradictoir ruling which means that the ruling applies in the ordinary lawsuit in case both parties are present so that no verzet but the Defendant can still file a legal action against the decision by filing an objection. The simplification of legal remedies in a simple lawsuit into such an objection may cause problems if the objection to the decision of a simple lawsuit judge, including the decision without the presence of the defendant (verstek), is based solely on the decision and the simple lawsuit, the objection petition and the objection memory as well as the objection counter and no additional checks are allowed, then there are the basic rights of the defendant that are not accommodated in the legal process. It is the principle that the process of examining civil cases the obligation to give equal rights and opportunities to both parties (audi et alteram partem). The same opportunity is not only to be heard but also in applying evidence to prove the truth of the arguments. The objective as intended by the existence of legal effort in PERMA Number 2 Year 2015 will not be achieved because there is no opportunity for the defendant to submit a proof of the objection arguments in the memory of the objection.

2. In simple lawsuit the domicile of the parties shall be in the same jurisdiction, this is not in line with the civil procedure law embracing the principle of the defendant's domicile (actor principle sequitur forum rei) that is authorized to hear a civil case is a District Court (PN) whose jurisdiction covers the defendant's residence. So according to the author is enough when filing a simple lawsuit in the Court domiciled defendant although the plaintiff is different domicile but because the plaintiff is an interested person it will not be difficult to call and process 25 days from the start of the first trial. And if the plaintiff uses a legal counsel 
JARES, Vol. 2 No. 1 March, 2017; p-ISSN: 2502-826X; e-ISSN: 2503-1163

Copyrights@ Balitar Islamic University, Blitar, Indonesia; Http://jares.unisbablitar.ejournal.web.id

Citation: Totok, Wiryatmo Lukito, et. al. 2017. Effectiveness in Implementing Supreme Court Regulation of The

Republic of Indonesia Number 2 Year 2015 on Procedures Settlement Of Simple Lawsuit in Settling the Civil Cases.

JARES, (2017), 2(1): 16-25

then it may use the domicile address of his / her attorney with the obligation of course the domicile address of the same legal counsel with the court examining the aquo case.

3. In a simple lawsuit, both parties shall be required to attend directly to each hearing with or be accompanied by a legal counsel whose domicile lawyer shall be located in the jurisdiction of the court adjudicating the aquo case. If either party as a plaintiff or a defendant is a legal entity and the head of a legal entity may authorize one of the employees of that company with due observance of the articles of association and the obligation to be present in each hearing is the employee concerned. However, it is the choice of the parties whether in a dispute in court that he uses the services of an attorney even though using a lawyer certainly requires high cost. So with the arrangement that although the party has used the services of a lawyer but still required to continue to attend the hearing then he felt in vain had paid the services of lawyers and of course affect the number of civil lawsuits filed through a simple lawsuit mechanism.

4. In the preliminary examination if the judge's opinion that the lawsuit is not included in a simple lawsuit because the proof is not simple, outside the land rights dispute and the settlement of the dispute is not made through a special court, the judge issues a stipulation stating that the lawsuit is not a simple lawsuit and the determination can not be made any legal effort. PERMA Number 2 Year 2015 does not explain the simple category or criteria of proof other than affirming explicitly not about land rights dispute because in the settlement of land dispute the proof is complicated and the time is long enough and local examination is required so that it must be completed within twenty five weekdays will not be achieved.

\section{b. Legal Culture Factors}

Issued by PERMA Number 2 of 2015 on the procedure for settlement of a simple lawsuit with the reason that the public will settle the case which is mainly the case of small nominal value in the Court, do not arise the perception of the community in solving the case in the Court as reporting the loss of goat resulted in the lost cow. Likewise, the pleasure or displeasure with pardon is part of the legal culture. The legal culture determines how the legal system obtains its logical place within the cultural framework of the general public and that efforts to grow a legal culture can achieve its result if the institutionalization process has been undertaken so that it needs to be socialized to the small community because the simple suit is oriented to the small community with more to increase the counseling of the law and to avoid the expression "noblesse oblige" that policies concerning the interests of the masses are only an important element in decision-making by the ruling elite.

\section{c. Factors of structure of the law}

It is demanded that the quality of the judge who examines the case is qualified in optimizing the time given to him to decide the case at the appointed time but still prioritizes the quality of the decision so as not to perfunctory but still prioritize (reasoning) clear legal considerations and enough that can be accepted by the logic because in order to be able to make a verdict of the court that really creates certainty and reflects justice for the litigants, the judge must know the true case and the legal rules that will be stipulated both written rules of legislation and regulations 
JARES, Vol. 2 No. 1 March, 2017; p-ISSN: 2502-826X; e-ISSN: 2503-1163

Copyrights@ Balitar Islamic University, Blitar, Indonesia; Http://jares.unisbablitar.ejournal.web.id

Citation: Totok, Wiryatmo Lukito, et. al. 2017. Effectiveness in Implementing Supreme Court Regulation of The

Republic of Indonesia Number 2 Year 2015 on Procedures Settlement Of Simple Lawsuit in Settling the Civil Cases.

JARES, (2017), 2(1): 16-25

of the unwritten law or customary law. So that against the verdict that does not meet the provisions of the categorized decision that is not enough consideration (onvoldoende gemotiveerd).

\section{d. Community Knowledge Factor about PERMA No.2 Year 2015}

Most correspondents only know about simple suits but do not know specifically about what a simple lawsuit is and there are about 3 people who are totally unaware of a simple lawsuit. Meanwhile, according to qualitative survey that is based on suggestion from respondent in general is more to socialization towards understanding of PERMA Number 2 Year 2015 by society through counseling of law of middle of society or by using internet media then mass media and pamphlet, brochure so that society more familiar about simple lawsuit.

\section{CLOSING}

The implementation of the Supreme Court Regulation (PERMA) Number 2 Year 2015 on the Procedure of Settlement of Simple Lawsuit for the Settlement of Civil Cases at the court of judges and court officials resulted that the simple lawsuit procedure was very effective in accordance with the simple, quick and low cost principle and from survey it was found that PERMA Implementation Performance Index Number 2 year 2015 about Simple Lawsuit at Court of Kediri District Class I B was equal to $64,53 \%$ or "GOOD" category (at interval 62.51 to 81.25).

Factors affecting the implementation of the Simple Lawsuit Settlement Procedure: a. Factor substance rule of the law, b. Factor of Legal Culture, c. Factors of structure of the law and d. Community knowledge factor about PERMA Number 2 Year 2015.

To immediately issue in the form of law or at least revise the law of civil procedure applicable in the country of Indonesia considering HIR and RBg has been so long that often no longer in accordance with the development so that finally to cover the legal void or to complete it issued SEMA or PERMA also prosecuted by a structural and substantial judicial prosecution to increase public confidence and belief while contributing to legal reform in Indonesia for the achievement of simple, fast and costly justice. There needs to be a revision to the PERMA regarding legal domicile, simple evidentiary criteria, and legal objection.

\section{REFERENCES}

Direktorat Jenderal Badan Peradilan Umum Mahkamah Agung RI,2015, Bimbingan Teknis Penyelesaian Perkara Gugatan Sederhana, Direktorat Jenderal Badan Peradilan Umum Mahkamah Agung RI.

Efa Laela Fakhriah, Eksistensi Small Claim Court dalam Mewujudkan Tercapainya Peradilan Sederhana, Cepat, dan Biaya Ringan. Hasil Penelitian Mandiri tahun 2012. Dosen 
Fakultas Hukum Universitas Padjadjaran Bandung pada mata kuliah Hukum Acara Perdata, Hukum Penyelesaian Sengketa, Hukum Kesehatan.

Esmi Warasih, Pengaruh Budaya Hukum Terhadap Fungsi Hukum, Satjipto Rahardjo, 1981, Francis Ward Stephanie, Oktober 2011 "Small Claims Court the "Fast Food" of the Legal System", American Bar Assiciation Journal, Vol. 9, No. 2. Hukum Dalam Perspektif Sosial, Alumni, Bandung.

Peraturan Presiden RI No 2 Tahun 2015 tentang Rencana Pembangunan Jangka Menengah Nasional (RPJMN) 2015- 2019 BUKU I Agenda Pembangunan Nasional, Kementerian Perencenaan Pembangunan Nasional/ Badan Perencanaan Pembangunan Nasional 2014.

Peter Mahmud Marzuki, 2009, Penelitian Hukum, Kencana Prenada Media Group, Jakarta. 